\title{
Avaliação Epidemiológica dos Fatores de Risco Anteparto para Ocorrência de Cesariana no Hospital Universitário Pedro Ernesto no Período de Junho de 1993 a Novembro de 1994.
}

Autor: Alfredo De Almeida Cunha

Orientadores: Prof. Dr. Luiz Camano e Prof. Dr. Abés Mahmed Amed

Tese de Doutorado apresentada a Disciplina de Obstetrícia da Escola Paulista de Medicina da Universidade Federal de São Paulo (Área de Concentração Obstetrícia) em 30/8/99.

Objetivos: 1. Identificar fatores anteparto relacionados à ocorrência de cesariana; 2. construir modelo preditivo de cesariana.

Pacientes e Métodos: Foram observados 843 partos assistidos na Maternidade do Hospital Universitário Pedro Ernesto da Universidade do Estado do Rio de Janeiro, unidade obstétrica de nivel III, no periodo de junho de 1993 a novembro de 1994. O delineamento do estudo foi de coorte do tipo retrospectivo. O critério de inclusão foi de recém-nascido vivo pesando $1000 \mathrm{~g}$ ou mais. A variável dependente foi cesariana, dicotomisada como presente ou ausente. As variáveis independentes foram os fatores anteparto relacionados à cesariana. Para a construção do modelo foi utilizada a regressão logística.

Resultados: O modelo multivariável mostrou risco de cesariana de acordo com as seguintes variáveis independentes: adolescência (idade inferior a 20 anos) $\mathrm{OR}=0,396$; idade materna igual ou superior a 28 anos $\mathrm{OR}=2,133$; antecedente de parto normal $\mathrm{OR}=0,626$; an- tecedente de cesariana $\mathrm{OR}=4,576$; assistência pré-natal $\mathrm{OR}=2,346$; apresentação pélvica $\mathrm{OR}=4,174$; gemelidade $\mathrm{OR}=14,065$; hemorragia da segunda metade da prenhe $\mathrm{OR}=28,189$; pré-eclampsia leve $\mathrm{OR}=2,180$; pré-eclampsia grave $\mathrm{OR}=16,738$; hipertensão arterial crônica $\mathrm{OR}=4,927$ e outras intercorrências maternas $\mathrm{OR}=2,012 \mathrm{O}$ modelo matemático mostrou concordância entre a probabilidade prevista e a resposta observada em $82,3 \%$.

Conclusões: 1. Foram identificados 12 fatores anteparto relacionados à ocorrência de cesariana. 2. Foi possivel construir modelo preditivo de cesariana utilizando os fatores de risco anteparto identificados no presente estudo. O modelo tem como aplicações previsão de cesariana, avaliação da qualidade da assistência, avaliação do impacto de intervenções e planejamento da assistência.

Palavras-chave: Resolução da gravidez. Cesareana. Parto normal.

\section{Prognóstico da Mola Hidatiforme pela Citometria Digital}

Autor: José Mauro Madi

Orientador: Prof. Dr. Hermógenes Chaves Netto

Tese de Doutorado desenvolvida e apresentada na Maternidade Escola da Universidade Federal do Rio de Janeiro em 21/12/99.

O objetivo do estudo foi o de prognosticar a evolução da mola hidatiforme para a cura espontânea ou doença trofoblástica persistente, pela citometria digital. Assim, estudou-se lâminas obtidas de blocos de parafina usados para o diagnóstico histológico da patologia molar com coloração pelo método de Feulgen. As pacientes foram divididas em 2 coortes quanto aos resultados citométricos: diplóides e não diplóides. Equipamento utilizado para a leitura das lâminas: PC 486 com $16 \mathrm{Mb}$ de memória RAM; placa de captura de imagem TARGAPlus $\AA^{\circledR}$; monitor de vídeo convencional; microscópio marca MEIJI® com câmara de vídeo acoplada da mesma marca; sistema operacional WIMG da Mcom Informática ${ }^{\circledR}$. A investigação foi do tipo coorte com distribuição dos dados obtidos em tabela de contingência e submetidos ao teste de qui-quadrado para se verificar a associação do diagnóstico citométrico com a evolução da doença, considerando-se significativa a asso- ciação quando $\mathrm{p}<0,05$. Os resultados mostraram que a citometria digital mostrou-se capaz de predizer a evolução da mola hidatiforme [(qui-quadrado com correção de Yates: $\mathrm{p}=0,0053$ - significativo; sensibilida$\mathrm{de}=0,76 \%$; especificidade $=77 \%$; valor preditivo positivo $=86 \%$; valor preditivo negativo $=63 \%$; redução do risco absoluto=0,49; risco relativo=2,30 $(1,20-4,43)$; "odds ratio" $=10,56(1,77-74,40)]$. Concluiu-se que a citometria digital, quando avaliada pelos testes de preditividade, mostrou-se capaz de prognosticar a evolução da mola hidatiforme. O exame, quando diplóide, denotou 2,3 vezes mais propensão da paciente acometida vir a desenvolver doença trofoblástica persistente do que aquela com citometria digital não-diplóide.

Palavras-chave: Doença trofoblástica gestacional. Citometria. Ploidia. 